\title{
THE STRIKES OF THE TYNESIDE KEELMEN IN 1809 AND I8I9
}

The keelmen, who transferred coal in keels or barges from the river banks to the waiting colliers at the ports of the north-eastern coalfield, had a history of industrial unrest during the eighteenth century, particularly on Tyneside. ${ }^{1}$ So early as 1671 there is an entry in Gateshead parish books which reads: "Paide for powder and match when the keelemen mutinyed 2s.", 2 and five strikes occurred between 1738 and 1771 . As a relatively powerful economic group, which, in the absence of any other method of transporting the coal from the inland pits to the colliers bound chiefly for London, could almost put a stop to the coal trade, the keelmen were often successful in obtaining consent to their demands, especially in the field of wages, where they were well-paid as compared with other labouring groups. In spite of this they had a continuing grievance, with regard to the overloading of the keels, which it was difficult to satisfy, even although an Act of Parliament, passed in 1787 , to establish a permanent fund for the support of sick and aged keelmen, had contained the following:

".... in order that the keels used on the River Tyne may be fairly and justly loaded, after the due and accustomed rate of eight chaldrons to each keel, be it enacted .... that no person or persons shall .... be capable of acting as an offputter or offputters at any coal staith upon the said river, until he or they respectively shall have taken and subscribed an oath ...."3

${ }^{1}$ Much of the history of the keelmen in the eighteenth century is recounted in three articles by J. M. Fewster in Durham University Journal, New Series, Vol. XIX. Three keelmen and a boy manned each keel, which was supplied by the coal-fitter of the particular colliery for which the keelmen worked on an annual bond.

Quoted in Sykes, Local Records, Vol. 1, p. 115.

3 Para. XIX of the Act, quoted in Bell Collection, Vol. XIII, p. 558. North of England Institute of Mining and Mechanical Engineers (hereafter cited as Mining Institute). The off-putter was an employee of the coal-owner who supervised the loading of coal into keels from the stocks at the staiths on the river banks, whence it had been brought by waggonway from the pit head. 
This grievance was to pass on into the nineteenth century, but more importantly as a powerful economic group the keelmen were having to face the challenge of a new method of transporting coal which could deprive them of their livelihood. In place of the old method of loading coal into the keels by hand a shute called a "spout" had been introduced at most of the staiths on the river, and in 1794 there were at least nine staiths below Newcastle bridge which had two spouts. At first these were used in order to load the keels more easily but gradually the smaller colliers were brought up the Tyne to the staiths where they received their cargo of coal directly by means of the spouts, thus depriving the keelmen of much of their work. One writer has gone so far as to suggest that "after about 1780 , the collieries that were opened below the Tyne bridges ceased to make use of keels and loaded coal direct into the vessels by means of spouts." 1 It is, however, certain that all the collieries below bridge continued to use some keels well into the nineteenth century, although for a declining proportion of their total output. The scene was thus set for the keelmen's strikes in the first quarter of the nineteenth century, which J. M. Fewster has, rather misleadingly since the keelmen were still important in midcentury, called "The last struggles of the Tyneside keelmen". ${ }^{2}$

In May 1803, the keelmen showed that they were going to continue to make as much capital as possible from their economic power. In that month 57 of them had been impressed for the navy and their fellows came out on strike in order to obtain their release ${ }^{3}$ The effect of this in disruption of the coal trade was sufficient to persuade the coal owners to support their workers and they eventually obtained the agreement of the Admiralty that the keelmen should be freed from impressment if they would voluntarily provide one-in-ten of their number (estimated at 800) for the navy. To this the keelmen objected and won the surprising concession from the Admiralty (no doubt as a result of the importance of the coal trade) that the keelmen should provide substitutes on the one-in-ten basis to be either landmen or seamen. Once this agreement was made the keelmen returned to work and although there was some further difficulty in 1811 over the impressment of keelmen who had started such work since 1803 , the victory of that year

1 F. Atkinson, The Great Northern Coalfield (Durham, 1966), p. 58.

2 Durham University Journal, New Series, Vol. XXIV.

8 This account and any future unacknowledged references have been taken from several bundles of uncatalogued papers on the keelmen in Newcastle City Archives. 
showed that they had considerable economic power and undoubtedly encouraged them to make use of it whenever they had the opportunity.

Such opportunity was provided by the price inflation experienced during the Napoleonic Wars. As a result the keelmen had a petition to Joseph Forster, the mayor of Newcastle, prepared, in which they requested an increase in wages of one shilling and six pence per tide (journey from the staith to the port of Shields) for coal carried from above Newcastle bridge and one shilling for the shorter journey from below bridge. This was presented on 29 August 1809 and at the beginning of September additions to the petition made more specific demands designed to compensate for loss of wages owing to bad weather conditions. 1

A date was arranged for a meeting of the coal trade ${ }^{2}$ at which delegates of the keelmen were present, armed with a memorandum of evidence in which it was stated that "The advance of Wages craved in the petition bears little proportion to the advance of provisions and necessaries since the year 1710 , nor the advances in Wages of the other Labouring Classes." Mr Strachan, a keelman, said that apart from 2/6d. for bread money and $1 / 2 \mathrm{~d}$. a tide for the above bridge men wages had not changed since 1710 . He considered that those keelmen with families should receive two pounds a week (which hints at the earning power of the group) and stated that the keelmen had difficulty in keeping their demands so low. After some discussion the meeting set up a committee of the coal trade to consider the petition.

A delay of several weeks occurred before a meeting of the full coal trade was called, on 30 September, in order to answer the petition. The meeting noted that in 1744 wages had been set at 15/8d. per trip for each keel taken from immediately above Newcastle bridge to Shields, ranging up to $17 /-\mathrm{d}$. from the most distant collieries and that there had been additions since that date. ${ }^{3}$ It was finally resolved that some addition for the above bridge keelmen was appropriate "but those employed at the staiths below already receive ample payment

1 The keelmen were paid on piece rates for each keel of coal delivered at Shields and, therefore, were not paid if they were prevented from sailing down the Tyne as a result of bad weather conditions.

${ }^{2}$ Consisting of representatives of colliery owners and the fitters or middlemen who were responsible for selling the coal and who employed the keelmen. Mining Institute, Easton Papers, Vol. IV.

3 A letter dd. 3 Oct. from Wm. Chapman, a coal-owner to Nathaniel Clayton, a coal-owner and town clerk of Newcastle upon Tyne, showed that the coal committee disagreed that wages had not been raised since 1710 . 
for their labour". It was recommended that payments for keels coming from between the bridge and Derwenthaugh should be $21 / 8 \mathrm{~d}$, from Denton (further up-stream) 22/8d., Lemington 23/4d., and Stella, the furthest coal-staith, 24/8d. These wages provided increments ranging from $1 / 10 \mathrm{~d}$. to $3 / 6 \mathrm{~d}$., which considerably exceeded the keelmen's demands.

The increases were, however, to be paid only to the above bridge men which suggests, since the existing ratio between wages above and below bridge had continued for over half a century, that the below bridge men were coming into serious competition with the spouts and losing their economic power, rather than that they were better paid than those above bridge according to the work done. This might have been expected to lead to a breakdown in the considerable unity of action which the keelmen had shown during the eighteenth century, with the above bridge men accepting the wage increase and the advantage they possessed that colliers could not pass under the bridge and leaving the below bridge men to their own devices. Indeed, this may have caused some dissension among the keelmen since they took no action for more than a fortnight after the offer was made by the coal-owners, during which period many were, doubtless, in favour of its acceptance.

On 19 October some of the below bridge keelmen decided to take matters into their own hands and struck work. It would, therefore, seem probable that the below bridge men realized their situation and were determined to improve it. Not only were they anxious to increase their wages but they were also aware of the inroads which were being made into their trade by the spouts and on 22 October a meeting of the coal trade was to be found discussing the fact that the below bridge keelmen had prevented ships from being loaded by spout at Felling and Walker and were thus endeavouring to make the strike more effective. The "Ambalator" of Scarborough, for instance, was casting ballast at Walker Quay when she was stopped by a party of keelmen who threatened violence if the work continued.

The action of the below bridge men in provoking a strike brought back memories of united action and they were joined by most of the above bridge men. The extent of the strike plus the existence of some violence had found the mayor, on 20 October, writing to LieutenantGeneral Dundas, commanding officer of the Northern Area, requesting the assistance of the military, since "a tumultuous body of people has this morning by force rescued a keelman who was taken up under a warrant issued against him." 1 As a result, by 26 October, the magis-

1 Since the keelmen were bound to their employers for one year, to strike was 
trates of Newcastle, whose jurisdiction extended over the full tidal length of the Tyne, were preparing plans for joint action with the military and the constables in order to try to control the actions of the keelmen who had been militant in preventing the carriage of coal on the river and in rescuing any of their number who should be taken up on warrants served by local constables.

Memoranda dated 26 October show that there were plans for two boat loads of constables with a magistrate in each to put out on the Tyne at 6.30 one morning to rendezvous with troops of horse, at Ouseburn on the north and Felling on the south shores, which would have moved down the banks of the Tyne from Newcastle. The aim would be to apprehend as many as possible of those keelmen against whom warrants had been issued. Instead of putting this plan into action the magistrates issued, on 27 October, a statement that the keelmen's petition would be re-considered if those on strike returned to work and the following day the magistrates received a deputation of 22 keelmen, but the negotiations failed to reach a successful conclusion. The magistrates were now being pressed by the coal-owners to take positive action to break the stranglehold on the coal trade of the river. The mayor, Isaac Cookson, swore in a number of special constables, and on 3 November, together with the other magistrates, he considered a plan submitted by the coal-owners and fitters for "reducing the keelmen of the River Tyne to a state of subordination". The plan was similar to that earlier described with the addition that the fitters would arrange for some loaded keels, manned by blacklegs, to be sent downstream in order to lure the keelmen to the river and would also provide guides who could identify those keelmen against whom warrants had been issued.

By now the mayor was becoming alarmed and wrote to Captain Charlton, the navy's regulating officer for the north-east, to the effect that the civil power could not prevent acts of violence and the stopping of any keels which attempted to run down to Shields and requesting that "you will lend all the assistance on the water that your boats properly manned can afford". On the same day, 3 November, he wrote to Sir Edmund Nagle, naval commanding officer at Leith, requesting a warship to be sent to Shields in order to prevent the keelmen from interfering with the trade of the river.

It seems most doubtful that such action was justified by the circumstances but Cookson's nerves must have been calmed by the receipt of a letter from Nagle, by return, informing him that the "Strenuous"

to break the agreement and they were, therefore, liable to legal action. Warrants for the arrest of at least 73 keelmen were issued on this ground during the strike. 
gun-brig had been ordered to Shields. The magistrates were now in the position to take determined action but their attitude was vacillating. There was consideration for putting the plan into execution on 4 November but the idea was postponed. The following day (Sunday) the magistrates issued a notice to the effect that all bound keelmen should return to work by Tuesday "in order to avoid the dreadful consequences of the law which must inevitably take place should they any longer persevere in their present line of conduct". The handbill stated that any keelmen returning to work would be protected, although the obvious incompetence of the authorities makes it dubious as to whether this could have been complied with. ${ }^{1}$

The fitters now proposed that if the keelmen did not return by the Tuesday the infantry should be sent to surround the major areas of keelmen's habitations below bridge in order to execute warrants against those men. The magistrates were not to be pressed but having threatened legal action they sent small parties of horse and infantry to various points along the river to remain there for several hours in order to show that some action was being taken. This had a quietening effect on the keelmen, to increase which the magistrates had enquiries made as to the accommodation available in the areas where the keelmen resided which could be used for quartering troops. As a result the mayor was able to write to General Dundas to the effect that there was quartering for about 250 men in various places above and below the bridge, apart from those stationed in Newcastle barracks and that "The above number of men are deemed necessary for the service required". There is no evidence of Dundas' reply but it seems unlikely that he would have been prepared to divide his command any further by sending more troops to Newcastle.

In the meantime, as a follow-up to their demand that the keelmen return on 7 November, the magistrates ordered that the water bailiff's and Newcastle quaymaster's boats should be ready to escort to Shields any keels which did return. There is no evidence that the mayor made use of the naval and military forces which he had so hastily called up and the only suggestion of protection was that pikes for "self-defence" would be made available to the crews of the two boats. Needless to say no keels availed themselves of the opportunity.

The magistrates' bluff had now been called, although the sending out of parties of infantry was having some effect in that a number of bound keelmen were taken up under warrants and brought before the magis-

1 Concern over the offering of protection was obviously limited. The draft notice offered a reward of 50 guineas for the conviction of anyone hindering a keelman in the discharge of his duty. Reflexion led to the substitution of 20 guineas and in its final form no mention at all was made of this. 
trates. Where they had been prevented from working, such as James Sword who had been stopped "by upwards of 100 keelmen", they were discharged but otherwise were committed to the house of correction for one month. ${ }^{1}$ By this time, however, the strike had reached the ears of the Home Office (not before time, considering the extent of the civil, military and naval forces involved) and Richard Ryder was writing to Cookson requesting details as to the strike and whether tranquillity had been restored. This placed the mayor in a quandary, since despite the forces at his disposal he had done little to break the strike. $\mathrm{He}$, therefore, delayed his reply, from 9 to 11 November, until he could make some acceptable comment. This might have been expected to have taken the form of all out pressure on the keelmen but, surprisingly it took the opposite form of requesting the coal trade to reconsider the keelmen's petition.

As a result on 10 November the members of the coal trade informed the magistrates that they were anxious to consider the keelmen's requests and would do so as soon as they returned to work and on the following day the mayor was to be found writing to the Home Office: "I would persuade myself that the Bulk of them (the keelmen) are about to return to Order and their Duty." That the mayor's "persuasion" was correct is obvious from the fact that two days later the magistrates wrote to General Dundas to inform him that the crisis was over and troops might be re-called.

The coal trade met very quickly to settle the keelmen's grievances in order to prevent any resurgence of the strike, their terms being shown to the magistrates on the fifteenth and offered to and accepted by the keelmen the following day. These terms were as follows: $1 / 10 \mathrm{~d}$. (per tide per keel) was to be added to the wages of all above bridge keelmen together with a further addition ranging from $1 /-\mathrm{d}$. to $2 / 4 \mathrm{~d}$. according to the distance of the staith above the bridge, to commence at the new binding time, 1 January 1810 . The below bridge men were to receive $1 / 6 \mathrm{~d}$. per keel per tide to be paid immediately since they "have this year carried per keel much less than usual "although" those above bridge have had at least equal work". In addition to these wages several other payments were agreed: 1 ) an addition of $2 / 6 \mathrm{~d}$. when a loaded keel had to waste a tide because of poor weather conditions; 2) $1 /-$ d. to keelmen going to the fitter's office for orders ; 3) 6 chaldrons of coal for firing to the men of each keel per year;24) Binding money

1 Newcastle Advertizer, 11 Nov. 1809. At least sixteen had been committed by this time.

${ }^{2}$ A chaldron was approximately equal to $53 \mathrm{cwt}$. 
was formally agreed to be as before, ranging from one pound per keel below bridge to three pounds at Lemington. ${ }^{1}$

From this settlement it is obvious that the keelmen had gained a considerable victory. ${ }^{2}$ Moreover they had once again learned that it is important to offer a united front to the enemy. The above bridge men had turned down a valuable offer in order to support their below bridge colleagues, even if rather unwillingly, but the ends had justified this. The below bridge men had obtained a wage increase which they would not otherwise have received, while the coal owners' previous offer to the above bridge men was exceeded by amounts ranging from eightpence to one shilling per tide according to the position of the staith. In addition all the keelmen were to benefit from the formalizing of the various other payments. It was obvious that the economic power of the keelmen was considerable, although in this instance it would seem to have been helped by the strange tactics of the magistrates. Having obtained considerable military and naval support (on the inadequate ground of one or two keelmen having been rescued when they had been arrested under warrants served by one constable alone) the magistrates made little use of them and were seemingly reluctant to break the strike by all out pressure on the keelmen, who were in the wrong as a result of having broken their bonds. This would seem even more surprising at a time when combinations of working men were illegal. Although there is no evidence that the keelmen had an organised combination in the form of a trade union, their strike was in restraint of trade and it is, therefore, interesting that there is no evidence to suggest that any prosecution under the Anti-Combination Acts was considered. It seems probable that similar strikes and combinations in other areas of the country were not proceeded against and that the effect of the Acts was more psychological than real. ${ }^{3}$

The reason for the comparatively lenient treatment of the keelmen lies mainly in their economic importance, although the smaller concession to the below bridge men shows that this was being circumscribed by the development of the spouts. It is, perhaps, to this economic power that the comparative uneventfulness of the strike should be attributed as compared with the near contemporary Luddite disturbances. The keelmen were in the classic position of an established

\footnotetext{
1 It had been customary at the time of making the bond for the ensuing year for the keelmen to receive binding money as an attraction to sign the bond.

${ }^{2} \mathrm{~J}$. M. Fewster must have been unaware of this document when he wrote of the 1809 strike: "It is not known whether the keelmen gained the increase in wages they had demanded." Op. cit., NS, XXIV.

3 Cf. M. D. George, "Combination Laws Reconsidered", in: Economic History, I (1927).
} 
working group being affected by industrial change but the particular circumstances of the Tyne insured that they retained some economic power and, therefore, remained relatively quiescent. ${ }^{1}$

\section{III}

For ten years after the strike of 1809 the keelmen showed little disposition to disturbance. To some extent this tranquillity was the result of cautious and reasonable treatment by their employers, as in 1812 when a meeting of the coal-fitters decided "in view of the high price of corn to render aid to certain (keelmen's) families over and above their earnings". ${ }^{2}$ Even in 1815 when a seamen's strike brought the coal trade to a stop and left the keelmen temporarily without employment, the latter body remained quiet and made no attempt to take sides in the dispute.

In September 1819, however, in depressed trading conditions with the spouts and a new invention called a "drop"3 reducing the amount of coal shipped by keel, the keelmen once again came out on strike. Coincident with the strike was the reform fever which hit the country after the Peterloo affair of the previous month, which, of course, coloured attitudes to it. ${ }^{4}$ There is, however, no evidence that the strike occurred as a result of radical feeling, or that the keelmen (one or two individuals apart) took any part in the reform activity. Moreover the radical reformers took surprisingly little interest in the strike. Beyond the issue of one or two handbills, ${ }^{5}$ nothing was done to draw the keelmen into reform - a surprising lack of the usual radical attempt to

1 By contrast, on the Wear, where the keelmen were being made redundant much more rapidly as a result of the shipping of coal by spout, there was a serious strike in 1815 during which many spouts were destroyed, the total value of the damage being estimated at $£ 6,000$. Sykes, op. cit., Vol. II, p. 89 .

2 Mining Institute, ZB20, Miscellaneous Papers of the Coal Trade, handbill, headed "Keelmen", dd. 18 Aug. 1812.

${ }^{3}$ The drop was attached to a staith and by means of pulleys enabled colliery waggons to be lowered over the hold of a vessel and the coal to be dropped directly in. Because of the shorter distance which the coal had to fall it was less broken and, therefore, more saleable in the market. It should not be thought, as some writing on the keelmen has suggested, that spouts and drops could only be used with colliers. They were in fact used below bridge to load coal into keels to be taken to the ships which could not come upstream because of their too great draught.

"For an account of "Tyneside Discontents and Peterloo", see the article by Dr N. McCord, Northern History, Vol. II, 1967.

5 Address of the Reformers of Fawdon to their Brothers and Pitmen, Keelmen and other Labourers of the Tyne and Wear (Newcastle, 1819), copy in Mining Institute, Bell Collection, Vol. XI, pp. 83-90. Address to the Pitmen, Keelmen and other Labouring Classes employed on the Tyne and the Wear (Durham, 
relate economic distress to lack of enfranchisement. The coincidence of the strike and reform meetings could not be overlooked in the eyes of the local authorities, however, and it must be remembered that their actions throughout the strike were tempered by fears of revolution.

The strike began on 27 September, a body of keelmen preventing keels from moving on the river, without any preliminaries in the way of attempts to have their grievances settled by negotiation. It would seem that the keelmen were relying on their earlier demonstration of economic power and were anxious to put pressure on their employers from the start. On the day after they struck they outlined their grievances in a petition to the coal-owners. ${ }^{1}$ They had "suffered very great Privations from want of Employment, chiefly owing to the Vend by Spout having increased so much of late" and requested that colliers should be allowed to load the equivalent of only six keels of coal at the spouts and receive the rest from keels. The Newcastle Courant spoke for the majority of local opinion. The keelmen were requesting

"the coal-owner or shipowner to substitute an expensive manual labour for a cheap machinery which is already erected and in operation; a demand wholly incompatible with all the acknowledged principles of freedom in trade. On the sole ground of the spouts being injurious to the navigation of the river could they be interfered with".2

In this criticism of the strikers, all the local newspapers, the radical Tyne Mercury included, were in unusual agreement.

The second point of the keelmen's petition was a request that only eight chaldrons of coal should be loaded in each keel, pointing out the danger the keels ran in time of strong tides or stormy weather. The third point had an indirect connexion with the first. Under the 1787 Act, one penny per chaldron of coal shipped by keel had been deducted from the keelmen's wages in order to provide for their hospital and charity. With the increase in coal shipped by spout, which did not pay the levy, the money raised was insufficient to support the hospital ${ }^{3}$ and the keelmen, therefore, requested that coal shipped by spout should also pay one penny per chaldron.

The coal trade acted promptly on receipt of the petition. On 29 September, John Buddle, secretary to the coal trade, issued a printed

14 Oct., 1819), an answer from the side of the established order. It is noticeable that these were not directed specifically at the Tyneside keelmen, but at the major labouring groups on both rivers.

1 Copy in Public Record Office, HO 42/196.

2 Newcastle Courant, 2 Oct. 1819.

3 The keelmen's fund had been in debt to the following extent in the preceding years: $1815 £ 47-13 /-; 1816 £ 98-1 / 5 ; 1817 £ 161-19 / 10 ; 1818 £ 101-2 / 5$. 
circular inviting interested members of the trade to a meeting on 2 October to consider the petition. This meeting held a fair discussion on the keelmen's situation and passed resolutions which in part conceded their demands. The coal-owners stated that they could do nothing about the spouts and any "attempt to do so would be a Violation of private Property, and of the principles on which all trade is carried on". 1 They were, however, prepared to contribute $£ 300$ towards the keelmen's fund, although not to accept any charge on shipment by spout, and agreed to tighten up on the limit of eight chaldrons per keel. This seemed a reasonable compromise in the circumstances, but it did nothing about the major grievance, that the spouts below bridge were reducing the keelmen's trade and, therefore, they rejected the resolutions.

In the meantime the local authorities had acted far more swiftly than in 1809. The day after the strike commenced the mayor, Archibald Reed, wrote to Lord Sidmouth at the Home Office and the Duke of Northumberland, informing them of the dispute and stating that he had no reason to suspect any radical influence. Even so he pointed out that the naval and military forces in the area were weak. In this letter began the anomaly of the strike - the general statement that little was to be feared in the way of disturbance while at the same time there was an increasingly hysterical demand for greater naval and military support. The Courant told its readers: "We do not understand that our hardy and honest watermen have been infected with the radical mania of reforming the constitution"2 and on 1 October Northumberland wrote to Sidmouth explaining that the dispute was only a local wage matter and not political. ${ }^{3}$

Despite these reassurances there was some concern with regard to the strike. On 30 September, a Mr Richardson of South Shields wrote to inform the mayor of the strike and that it was "only the forerunner of that awful Rebellion, Plunder and Rapine, now in embryo" which would occur if the law did not act. On 3 November, Nicholas Fairles, a rather autocratic Durham magistrate, informed Sidmouth that there had been some trouble with the keelmen preventing ballast being unloaded from ships at South Shields which were to proceed up the Tyne to load at the spouts. He had sworn in a number of special constables to prevent any repetition and was all in favour of using force to break the strike. ${ }^{4}$

1 Northumberland Record Office, Minutes Joint Cttee. of the Coal Trade of the Tyne and Wear, 1819: PRO, HO 42/196.

2 Newcastle Courant, 2 Oct. 1819.

3 PRO, HO 42/196.

Ibid. 
The authorities directly involved were also becoming concerned about the affair. On 4 October, the Duke of Northumberland informed the Home Office that there were a large number of ships idle in Shields harbour and commented that although the pitmen and sailors were quiet at the moment, "there is no military or naval force should they become tumultuous". "The following day Archibald Reed thought that he had convinced a large meeting of keelmen that they must return to work before he could do anything about their petition, but they later decided to remain on strike. ${ }^{2}$ As a result of this decision the mayor wrote to Sidmouth on 6 October that he feared the pitmen and sailors would soon be in a state of insubordination and that the magistrates could not protect the port "without a strong naval force". The same day he wrote to ask the Northumberland and Durham magistrates for their assistance and to General Byng (officer commanding Northern District) requesting "at least four companies of infantry". The Home Office, itself very concerned about radical activity and unaware as to how far the keelmen's dispute might be linked with this, had already, on 1 October, requested the Admiralty to send a sloop of war to the Tyne and on the seventh Sidmouth informed Northumberland that the 7th Dragoon Guards would be available to reinforce the troops at Newcastle if necessary.

After the flurry of letters written by the mayor there was little concern about the keelmen whose importance paled into insignificance beside the threat of the forthcoming Newcastle reform meeting to consider the Peterloo affair. Joseph Bulmer, a rather unreliable acting magistrate, informed the Home Office: "I dread Monday (the day of the reform meeting), the keelmen are living by plunder - taking turnips and potatoes from the farmers in open day." 3 There was no evidence to support this statement, nor the implied connexion between keelmen and reformers, the former appear to have behaved quite peaceably. Certainly Reed's comment, "I have not the least dread of the result", with regard to the meeting, would have carried more weight at the Home Office. He was enabled to vindicate this view after the meeting,

1 Ibid., On 2 Oct. the Durham County Advertizer had claimed that the keelmen had deliberately timed their strike for a moment when there were a large number of ships awaiting cargoes of coal, thereby causing maximum dislocation in the coal trade.

2 According to Reed's letters to the Home Office (6 and 9 Oct.) the keelmen decided to remain on strike until after the eleventh, the day when the Newcastle reform meeting to consider the Peterloo affair was to be held. This is hardly credible in the light of all the contemporary statements that the keelmen, as a body, took no part in the meeting. It would seem more likely that the keelmen remained on strike in the hope of obtaining a better settlement.

3 PRO, HO 42/196, Joseph Bulmer to Lord Sidmouth, 8 Oct. 1819. 
everything having passed off quietly and even Nicholas Fairles had to comment that the keelmen took little part in the meeting. ${ }^{1}$

With the meeting over the strike again began to cause concern. The Newcastle Chronicle wrote: "We regret to state that they (the keelmen) have this week threatened to pull down some of the staiths"2 and on 13 October the magistrates of Chester Ward, County Durham, informed the Home Office: "from the Proceedings upon the River Tyne and the general state of the Ward we are unable to answer for the preservation of the public peace without an increase of the military force."3 Since there were already a sloop of war and two gun brigs on the Tyne and several troops of dragoons stationed in Newcastle this was probably ignored. The events of the following day, however, showed this request to have been almost prophetic.

On 14 October, Reed, under pressure from the coal-owners to open the navigation of the river, went in the harbour-master's boat with a force of constables to escort some laden keels down to Shields. ${ }^{4}$ In addition four boats from the warships accompanied the party and the magistrates for Northumberland and Durham together with military forces were out on their respective banks of the river. The keels reached Shields without event, where they tied up alongside a collier in order to unload. The owners then stated that they only wanted some constables left to guard the work. The naval boats were dismissed and Reed retired to the Northumberland Arms for refreshment, leaving the constables in the steam packet, the Speedwell, on guard. Reed, himself, stated: "There did not seem the least reason to suspect riot, or an attack upon the packet" although he had been greeted "with hisses and shouts" by a crowd on the quay when he landed.

While Reed was at the inn the crowd became incensed at the sight of the keels being unloaded and breaking the strike and began threatening the keelmen. Some stones were thrown and for safety at least one of the keels went alongside the packet whereon the crowd commenced stoning that boat, which was "not above five yards from the shore" with its steam let off and could not, therefore, be moved. A message was sent to the mayor for help but he could not get to the packet since "Between 3 and 400 of the mob were on the Quay showering stones"

1 Ibid., Fairles to Sidmouth, 12 Oct. 1819.

2 Newcastle Chronicle, 16 Oct. 1819.

3 PRO, HO 42/196.

4 The detail of the events is confused and conflicting and this account has been compiled from that in Reed's letter to Sidmouth (PRO, HO 42/197, 17 Oct. 1819) and accounts by the keelmen who were manning the keels taken to Shields (Keelmen's Papers, Newcastle City Archives). These informants all came under attack during the affair and on this count their reports are possibly exaggerated. 
into it. Two boats from the warships loaded with marines were sent in assistance and in the confusion someone gave the order to fire in the air, which two marines did. This further incensed the crowd who renewed their efforts at stoning and several shots were then fired at the crowd, one of which killed a man called Joseph Claxton.

In the meantime Reed had made another unsuccessful attempt to get to the packet but on this occasion he had taken prisoner a shoemaker, one of the radicals who had taken part in the reform meeting at Newcastle, and taken him to the inn. When the shots were fired from the boats Reed again ventured onto the quayside but was forced to retreat to the inn when the crowd turned on him, thinking that he had given the order to fire. The inn was attacked, its windows smashed and just when it seemed that the mob would break the door down, Joshua Donkin, the High Constable of Tynemouth, arrived and pacified the crowd by telling them that it was impossible for Reed to have ordered the marines to fire. The mob then demanded that the prisoner be released and for the moment that pacified them but the remembrance of the man killed earlier led to shouts of "blood for blood" and a renewed attack on the inn. The mob soon broke in and searched the building but the mayor and his companions had escaped by the back exit and returned to Newcastle.

A rather inaccurate report of the affair was sent to the Home Office by Joseph Bulmer. One interesting point made in his letter, however, was that "The keelmen were joined by a great number of the Radicals of North Shields." 1 In the various reports of the incident, including that made by Reed, keelmen were not mentioned as comprising the mob. The man arrested was a shoemaker, the man shot a seaman and a witness close to the latter in the crowd a publican. This leaves some doubt as to how far it was keelmen, objecting to the strike-breaking, who caused the riot. It would certainly seem unlikely that there were many keelmen at Shields since their homes were mainly in Newcastle and the military forces on the river banks would have prevented any large body from reaching Shields. The report in the Tyne Mercury confirms this impression. ${ }^{2}$ Taking the radical viewpoint, whereas it had not supported the keelmen, it stated that stones had been "thrown by some idle boys, said to be urged thereto by the women" and that the crowd had only got out of control when the "unexpected act" of the marines' firing had occurred. It may well be that Reed's report was coloured in order to justify demands for further military assistance.

At ten o'clock that evening Reed gave a brief account to the Home

1 PRO, HO 42/196, Bulmer to Sidmouth, 15 Oct. 1819.

2 Tyne Mercury, 19 Oct. 1819. 
Office and requested the assistance of further military, ships of war and marines. He also wrote to the commanding officer at Sunderland requesting as large a body of infantry as possible "without an hour's delay", to General Byng for further support and to the Earl of Darlington that the South Tyne Yeomanry Cavalry be called out. It is obvious that Reed was slightly unhinged by his experience and unable to view the situation dispassionately, as for instance he had done with the reform meeting. His requests, however, were rapidly complied with. Four companies of the 40th Foot arrived from Sunderland the following morning; Byng and Sidmouth arranged for reinforcements and Darlington called out the yeomanry.

The calling out of the South Tyne Yeomanry and subsequently the Axwell and Bywell Yeomanry would seem to have been a dangerous measure considering the feeling that existed after Peterloo and it caused Sidmouth to write to the mayor hoping that the yeomanry "would not be called upon to act, except in case of emergency". ${ }^{1}$ That there were no repercussions on Tyneside probably emphasizes the error which Reed made in supposing that the area was seriously disaffected. There were no further incidents, produced either by the keelmen or the reformers, although the authorities remained in a state of nervousness.

As a result of the affair at Shields a Court of Inquest was held under an Act passed in the reign of Henry IV, presided over by Thomas Clennell, Chairman of Northumberland Quarter Sessions. The jury found Thomas Gustard, the shoemaker caught by Reed, guilty of participation in a riot, although his sentence, a fine of 20 shillings and binding over to keep the peace, was very light. No-one else was brought for trial, despite the offer of a reward for evidence leading to a conviction and the only other legal result was a verdict of justifiable homicide at the inquest on Joseph Claxton. To this several people took exception, since shots were fired into the houses of two of the jurymen. It was suggested that this "outrage" was perpetrated by keelmen but there is no evidence to prove this.

In the week after the incident at Shields the keelmen's dispute was moving towards a settlement. On 17 October Reed informed Sidmouth that he expected "the keelmen and the owners to settle their business tomorrow" but he was still concerned about the radical reformers and requested further reinforcements. The removal of the problem of the keelmen was the result of patient mediation by Thomas Clennell. As early as 7 October Reed wrote to Sidmouth: "My brother Magistrate, Mr. Clennell, had an interview with about 300 of the keelmen yesterday

1 PRO, HO 41/5, 19 Oct. 1819. 
evening which is likely to produce good effects." 1 Clennell eventually obtained an improvement in the original terms offered by the coalowners to the keelmen but this was turned down by the keelmen, who made the additional demand that employment should be found for those of their number who were unemployed (about 100-150). This request offered little problem and on 20 October Reed could write to Sidmouth: "The coal owners have acted most liberally and the corporation of this town offered to employ every keelman who had not work". 2

While Reed was writing the keelmen met to consider these terms and the following day he wrote that all was well and the keelmen would return tomorrow. In the meantime all the collieries but two had advanced some money to their keelmen in order that they might buy provisions. The remaining two collieries would not make this concession and Reed, fearing that this might lead to a renewal of the strike, offered an advance of 20 shillings to the keelmen of these collieries. This solved the problem and Reed could state that the keelmen were back at work and satisfied and could even contemplate with equanimity the drawing up of plans for the return to their respective bases of part of the naval and military forces.

\section{IV}

Once again the Tyneside magistrates had muddled through a strike of the keelmen. They had again made unsuccessful efforts to break the strike with the civil power, followed by frantic demands for military assistance which was little used when it arrived. ${ }^{3}$ It confirms a basic tendency to treat the strikes as local economic affairs and interfere very little, but to require a competent peace-keeping force in the event of serious trouble. This was unusual, at a time of war in 1809 and considerable unrest in 1819 and in both instances during a period when the combination acts were in force and industrial combinations supposedly illegal. The magistrates were undoubtedly very reasonable in their treatment of the keelmen's disputes and failed to act in the repressive way which it is traditional to expect of the period, although there seems no adequate reason for this expectation. There were a

1 Ibid., 42/196.

2 Ibid., 42/197.

${ }^{3}$ That such forces could be used effectively was seen during the seamen's strike of 1815 , when in one straightforward action the magistrates, making use of a military and naval force, took control of Shields harbour and crushed the strike. See the article on the strike by Dr N. McCord in the Economic History Review, Vol. XXI, No 1 . 
number of reasons why the magistrates did not act to break the strike. Firstly, there had been a long history of strikes by the keelmen which the magistrates had always tended to treat as local economic affairs which should be settled by mediation. Secondly, in the two examples with which this paper is concerned there can be little doubt that the Newcastle magistrates, mainly Whigs of liberal persuasion, felt that many of the grievances about which the keelmen were striking justified such action, particularly the claim for higher wages during the period of price inflation which preceded the first strike and the demand for the eight chaldron rule to be observed. Thirdly, during the 1819 strike it was obvious that the magistrates did not wish to take any action against the keelmen which might drive them into the arms of the radical reformers. Finally, the keelmen played an important part in the coal trade, on which much of the prosperity of the region depended, and the magistrates were undoubtedly opposed to taking action which might deepen the nature of the dispute and increase ill feeling in the area. As far as the keelmen were concerned the strike again showed their economic power, although in a lesser degree than in 1809. Once again they achieved greater concessions than the coal-owners were prepared to give before the strike.

The agreement negotiated by Clennell contained nine points. ${ }^{1}$ The coal-owners agreed not only to pay $£ 300$, already offered, to the keelmen's fund within one week of their return to work, but more importantly to an Act of Parliament being obtained for a charge of one farthing, on every chaldron of coal shipped from the river, to be paid to the fund. Thus the keelmen partially obtained one of the major points of their petition, which they would not have got without the strike. Secondly, the keelmen were to be paid for the coal over the normal eight chaldrons which they had carried since the beginning of the year (which showed that the owners had deliberately evaded the eight chaldron rule). Thirdly, the keelmen were to receive a duplicate of their annual bond, which meant that they knew their terms of hiring. Fourthly, they were to be paid two shillings and six pence per keel if they had to load the keel with coal by hand and this was always to be paid in cash. This was an attempt to dispose of the old grievance that the keelmen were forced to take part of their wages in drink provided by the coal-fitters. Fifthly, they were to be paid one shilling per keel for casting coal into the colliers for every foot that the coal-port was above the gunwale. With the increase in size of ships the keelmen had

1 Newcastle Chronicle, 30 Oct. 1819. The MS original of the agreement, signed by Thomas Clennell and Joshua Donkin, dd. 20 Oct. 1819, is in Mining Institute, Miscellaneous Deposits, ZA 19. 
complained of the extra work in unloading their cargoes. Since this sum was to be paid by the captains of ships the harbour-master was made arbiter of any dispute. Sixthly, a procedure was laid down in an attempt to prevent future strikes. Two keelmen were to apply to a magistrate, who was to convey their complaint to John Buddle, without mentioning their names, so that it could be considered by the coal trade. Seventhly, the off-putters were to be sworn to keep to the eight chaldron limit. Eighthly, one pound was to be paid to each man at the binding time in aid of house rent (the high cost of which had been one of the men's grievances). Finally, the Corporation of Newcastle agreed to employ all unemployed keelmen in dredging work. The agreement also gave the assurance that "None of the keelmen will be discharged for anything that has passed and they shall all be bound again.

It will be seen from the above that the keelmen came out of the strike with considerable gains, at least on paper. They had provided very soundly for their fund; obtained a firm decision on the eight chaldron rule and some wage increases; and achieved a number of important points in writing. That their economic power was declining was shown by the keelmen's failure to make any impression on the owners with regard to loading by spout, the very cause of that decline. The coalowners were not prepared to accept any violation of their rights of property and although Clennell stated that he had advocated the keelmen's cause with regard to the spouts and that a petition to the Common Council "will meet with every attention", nothing came of this. Thus, even at a time of considerable achievement, there were black clouds on the horizon of the keelmen's future. ${ }^{1}$

1 I deal with the subsequent history of the keelmen in an article which is to be published in the 1968 jssue of Northern History. 